\title{
СУЧАСНІ ПОГЛЯДИ НА МОРФОЛОГІЧНУ ДІАГНОСТИКУ НАЙПОШИРЕНІШИХ СЕРЦЕВО- СУДИННИХ УСКЛАДНЕНЬ COVID-19 ЗА ДАНИМИ ЛІТЕРАТУРНИХ ТА ВЛАСНИХ ГІСТОЛОГІЧНИХ ДОСЛІДЖЕНЬ
}

\author{
๑Д. Б. Коваль, Д. О. Кошовська, Т. К. Головата, А. З. Миколенко, Ю. М. Орел \\ Тернопільський національний медичний університет імені І. Я. Горбачевського МОЗ України
}

PEзЮME. Проблема вивчення патогенетичного впливу SARS-COV-2 на дихальну і серцево-судинну системи в організмі людини актуальна, оскільки ураження серця і коронарних судин $\epsilon$ причиною численних летальних випадків і розвитку ускладнень, які значно погіршують якість життя.

Мета - дослідити патогенетичні та морфологічні особливості основних серцево-судинних ускладнень при COVID-19.

Матеріали і методи. Проведено аналіз наукової літератури та гістологічне дослідження серця 4-х пацієнтів, померлих від серцево-судинної недостатності в лікарнях Тернопільської області з лабораторно підтвердженою коронавірусною інфекцією.

Результати. Доведено, що серцево-судинні ускладнення COVID-19 пов'язані з ушкодженням ендотелію, гіперкоагуляцією (тромбоемболія легеневої артерії, інфаркт міокарда, інсульт) та системним запаленням (міокардит).

Висновки. Причинами розвитку гострої серцево-судинної недостатності при коронавірусній інфекції $\epsilon$ альтеративно-запальні зміни паренхіматозного компонента міокарда, гіперкоагуляція і ушкодження ендотелію судин.

КлючОВІ СлОВА: COVID-19; ендотеліїт; інфаркт міокарда; міокардит.

Вступ. Згідно з даними сучасних наукових досліджень, серцево-судинні ускладнення $є$ поширеною знахідкою і основною причиною смерті під час пандемії COVID-19. Це пов'язано з механізмом інвазії вірусу, пошкодженням ендотелію та загальною імунною відповіддю організму людини. SARS-COV-2 вважається більш вірулентним, ніж SARS-COV, оскільки вірус в основному вражає дихальну і серцево-судинну системи організму людини. Значну частку становлять ураження серця і коронарних судин, що і $\epsilon$ причиною численних летальних випадків і розвитку ускладнень, які значно погіршують якість життя [1]. Інфекція SARS-CoV-2 уражає головним чином дорослих, менше випадків повідомляється у дітей віком від 15 років. Слід зазначити, що через наявність недіагностованих, безсимптомних або легких форм хвороби цей показник дуже варіює.

Досвід попередніх епідемій коронавірусу та грипу свідчить про те, що вірусні інфекції можуть спровокувати гострий коронарний синдром (ГКС), аритмії та розвиток гострої серцево-судинної недостатності, в основному, за рахунок поєднання значної системної запальної реакції, локального судинного запалення, розміру атеросклеротичної бляшки. Зрозуміло те, що коронавірусна хвороба 2019 р. може викликати нову серцеву патологію та/або призвести до загострення наявної патології серцево-судинної системи [2]. Незважаючи на те, що механізми серцево-судинних проявів COVID-19 ще недостатньо з'ясовані, ряд авторів пропонують наступні можливі варіанти: пряма кардіотоксичність; системне запалення; коронар- ний тром6оз; несприятливі наслідки терапії під час госпіталізації; сепсис, що призводить до ДВЗ; посилення системного тромбогенезу; електролітний дисбаланс [3]. Повідомляється, що пошкодження міокарда в основному відбувається внаслідок безпосереднього вірусного ураження кардіоміоцитів та наслідків системного запалення.

Мета нашої роботи - на основі власних спостережень та даних наукової літератури проаналізувати патоморфологічні особливості ураження серця при COVID-19 та виділити основні структурні зміни в тканинах.

Матеріал і методи дослідження. Гістологічно досліджено серця 4-х пацієнтів, які померли від серцево-судинної недостатності в лікарнях Тернопільської області. У всіх випадках лабораторно була підтверджена коронавірусна інфекція. Після загальноприйнятого парафінового проведення гістологічні зрізи забарвлювали гематоксиліном і еозином. Препарати досліджували під світловим мікроскопом Olympus CX22. Необхідні для демонстрації гістологічні препарати фотографували. Зображення на монітор комп'ютера виводили з мікроскопа Olympus CX22 за допомогою відеокамери VISION Color CCD Camera і програми Inter Video Win DVR.

Результати й обговорення. Мікроскопічне дослідження гістологічних препаратів сердець пацієнтів, які померли від коронавірусної інфекції, показало цілий комплекс структурних змін. Насамперед ми звертали увагу на морфологічні особливості гемоциркуляторного русла. Оскільки наступною ланкою патогенезу коронавірусної 
Огляди літератури, оригінальні дослідження, погляд на проблему, випадок з практики, короткі повідомлення інфекції після реплікації вірусу SARS-COV-2 в епітелії верхніх дихальних шляхів є вірусемія, логічним $\epsilon$ твердження про пошкодження судинної стінки як першого компонента гістогематичного бар'єру. Ендотеліоцити артерій малих розмірів та артеріол розташовувалися на базальній мембрані нерівномірно, невеликими групами чи поодинці. На значному протязі базальна мембрана залишалася «оголеною». Тільки окремі клітини зберігали звичайний вигляд. Більшість клітин ставали округлими із світлою пінистою цитоплазмою та пролабували в просвіт судин. Також візуалізувалися десквамовані ендотеліальні клітини. У місцях десквамації клітин виявляли пристінкову агрегацію еритроцитів та явища тромбоутворення. Також виникали передумови для внутрішньосудинної плазморагії та транссудації плазми у перивазальний простір. Еритроцитарних екстравазатів ми не спостерігали. Судинні стінки втрачали компактність, з'являлися клітинні інфільтрати (рис. 1).

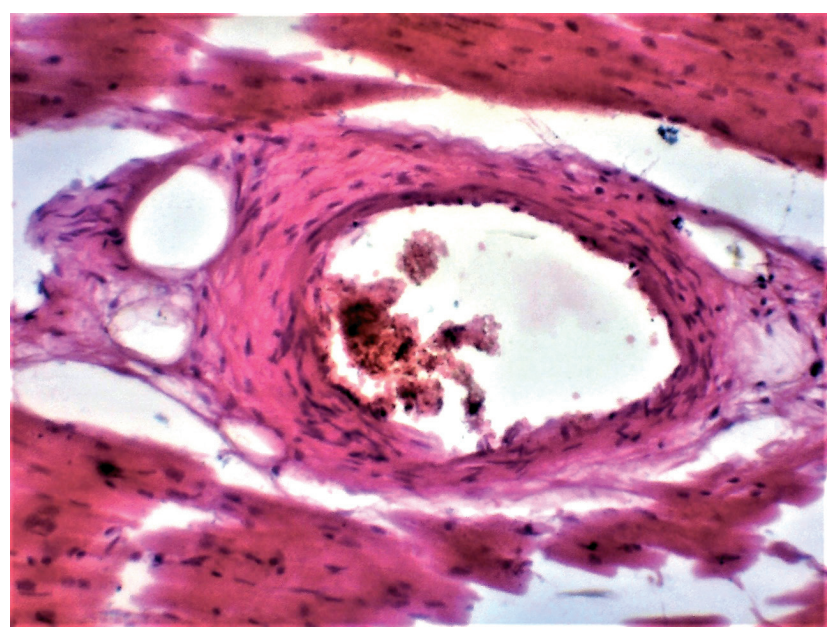

Рис. 1. Фрагмент міокарда із поперечним зрізом судини м'язового типу: ендотелій на значному протязі злущений, формування пристінкового тромбу. Забарвлення гематоксиліном і еозином. × 200.

Аналіз літературних джерел підтверджує, що вірус SARS-COV-2 проникає в організм через верхній респіраторний канал, проте його вибіркове прив'язування до рецепторів АПФ-2, розташованих як в ендотелії респіраторних шляхів, так і в ендотелії артерій і вен, засвідчує, що COVID-19 значно більшою мірою є судинною інфекцією, ніж легеневою [2]. У різних описаних випадках при гістологічному дослідженні та методом імуногістохімії виявляли ознаки лімфоцитарного ендотеліїту в судинах легень, нирок, мезентеріальних судинах. Ці зміни наштовхнули авторів уперше висловити твердження, що ураження органів (у тому числі легень) при COVID-19 є наслідком ендотеліїту. Ендотеліальна дисфункція, як відомо,

призводить до гіперкоагуляції, вазоконстрикції та ішемії органів, а також до набряку тканин унаслідок запалення. Ряд авторів виявляли як включення самого вірусу в ендотеліальних клітинах, так і накопичення клітин запалення (лімфоцитів) - тобто, до запалення ендотелію призводять як пряме ураження вірусом, так і власна імунна відповідь організму господаря. Ендотеліїт $є$ поясненням порушень мікроциркуляції в різних системах органів.

Причиною тромбозів $\epsilon$ як пряме пошкодження ендотелію судинної стінки, так і здатність вірусу викликати гіперкоагуляцію внаслідок вивільнення протромботичних цитокінів під час вираженого системного запалення та імунної відповіді організму. До небезпечних тромботичних ускладнень COVID-19 належать ГКС, венозні тромбози та тромбоемболія легеневої артерії (ТЕЛА), ішемічні інсульти та ішемічні ураження інших органів і систем. Такі серцево-судинні ускладнення можуть трапитися у будь-якого пацієнта із COVID-19, однак у пацієнтів із наявним серцевим захворюванням ризик їх виникнення та тяжкість перебігу набагато більші. Венозні тромбози та ТЕЛА $є$ найчастішим тромботичним ускладненням COVID-19.

Інший механізм, про який повідомляється все частіше, специфічний для COVID-19, - це тромбоз коронарної артерії без попередньо існуючого атеросклеротичного ураження. При COVID-19 явище тромбування коронарних артерій є дуже специфічним ускладненням унаслідок вираженої гіперкоагуляції. Таким є повідомлення про IM тромботичного походження у пацієнта з COVID-19 із масивним дифузним тромбозом правої коронарної артерії (ПКА), який проникав у всі гілки ПКА без ознак атеросклеротичного ураження коронарних артерій на фоні лікування COVID пневмонії [6] .

Суттєві структурні зміни спостерігалися і в паренхіматозному компоненті міокарда. На тлі паретичного венозного повнокров'я та інтестиціального набряку ми виявляли ділянки круглоклітинної інфільтрації переважно лімфоцитами. Інфільтрація поєднувалася і нашаровувалася на виразні альтеративні зміни кардіоміоцитів - осередкові некрози, глибковий розпад, фрагментацію та деформацію розташування серцевих клітин (рис. 2, 3).

Констатовані структурні пошкодження кардіоміоцитів та запальна судинно-стромальна відповідь складають морфологічну основу різкого зниження скоротливої можливості міокарда.

У сучасних літературних джерелах описані пошкодження міокарда з розвитком гострої серцевої недостатності, які стали безпосередньою причиною смерті в 7 \% випадків і сприяли смерті у $33 \%$ пацієнтів [4].

При аутопсії пацієнтів, які померли від COVID-19, ряд авторів описують наявність пери- 
Огляди літератури, оригінальні дослідження, погляд на проблему, випадок з практики, короткі повідомлення

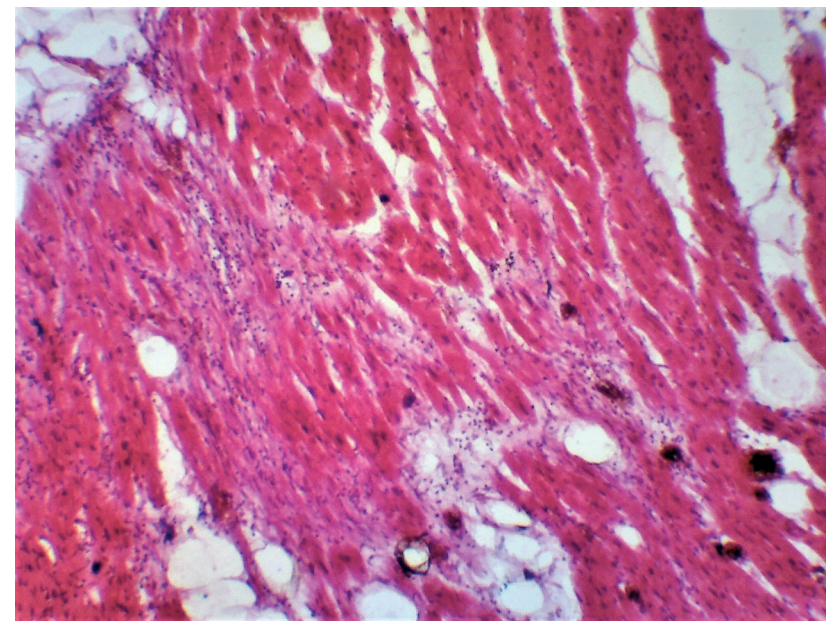

Рис. 2. Гістологічний зріз міокарда пацієнта, який помер від коронавірусної інфекції. Інтенсивна дифузна запальна інфільтрація та множинні некрози кардіоміоцитів. Забарвлення гематоксиліном і еозином. × 100.

кардіального серозного випоту, мікроскопічні дослідження вказують на дифузну лейкоцитарну інфільтрацію міокарда, представлену лімфоцитами, еозинофілами, макрофагами і окремими гігантськими клітинами, місцями з формуванням гранульом [5]. Крім того, в міокарді як правого, так і лівого шлуночків серця, виявляють множинні осередки некрозу, що свідчить про альтернативний характер запалення. При цьому знаходять запальні зміни коронарних судин [6].

Висновок. Серцево-судинні ускладнення при ураженні вірусом SARS-COV-2 представлені дво-

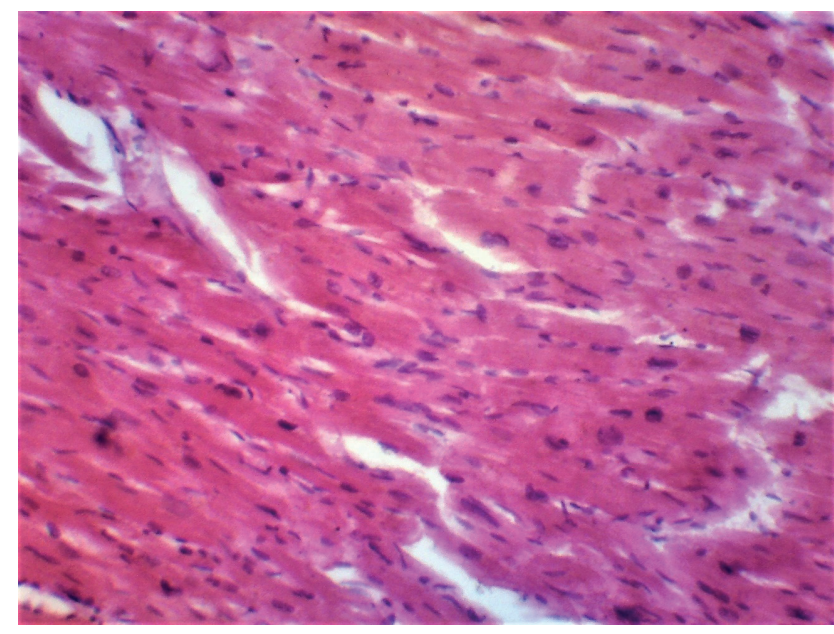

Рис. 3. Гістологічний зріз міокарда пацієнта, який помер від коронавірусної інфекції. Дистрофічно змінені кардіоміоцити фрагментовані. Забарвлення гематоксиліном і еозином. × 200.

ма типами структурних змін: 1 - судинна патологія, пов'язана з ушкодженням ендотелію (ендотеліїт, васкуліт) та гіперкоагуляцією; 2 - альтеративно-запальні зміни паренхіматозного компонента міокарда, які лежать в основі зниження контрактильної здатності міокарда і на кінцевому етапі гострої серцево-судинної недостатності.

У перспективі подальших досліджень планується провести комплексне морфологічне дослідження внутрішніх органів пацієнтів, померлих від наслідків коронавірусної інфекції.

4. Аналіз впливу коронавірусної інфекції на серце / А. С. Єрмоленко Є. М. Лісова, С. Н. Шарун, Т. В. Бочарова//Wissenschaftliche Ergebnisse und Errungenschaften.2020. - № 2. - P. 43-44.

5. Комісаренко С. В. Полювання вчених на коронавірус SARS-COV-2, що викликає COVID-19: наукові стратегії подолання пандемії / С. В. Комісаренко // Вісн. НАН України. - 2020. - № 8. - С. 29-71.

6. Орищин Н. Серцево-судинні ускладнення у пацієнтів із COVID-19: опис клінічного випадку та огляд літератури / Н. Орищин, Ю. Іванів // Праці НТШ Медичні науки. - 2020. - № 2 (62). - С. 87-98.

\section{REFERENCES}

1. Tian, S., Xiong, Y., Liu, H., Niu, L., Guo, J., Liao, M., \& Xiao, S.-Y. (2020). Pathological study of the 2019 novel coronavirus disease (COVID-19) through postmortem core biopsies. Mod. Pathol., 33 (6), 1007-1014. DOI: 10.1038/ s41379-020-0536-x

2. Hoffmann, M., Kleine-Weber, H., Schroeder, S., Krüger, N., Herrler, T., Erichsen, S., \& Pöhlmann S. (2020). SARSCoV-2 Cell Entry Depends on ACE2 and TMPRSS2 and Is Blocked by a Clinically Proven Protease Inhibitor. Cell, 181 (2), 271-280.e8. DOI: 10.1016/j.cell.2020.02.052 
Огляди літератури, оригінальні дослідження, погляд на проблему, випадок з практики, короткі повідомлення

3. Sakai, K., Ami, Y., Tahara, M., Kubota, T., Anraku, M., Abe, M., \& Takeda, M. (2014). The host protease TMPRSS2 plays a major role in in vivo replication of emerging $\mathrm{H} 7 \mathrm{~N} 9$ and seasonal influenza viruses. J. Virol., 88 (10), 5608-5616. DOI: https://doi.org/10.1128/JVI.03677-13

4. Yermolenko, A.S., Lisova, Ye.M., Sharun, S.N., \& Bocharova, T.V. (2020). Analiz vplyvu koronavirusnoi infektsii na sertse [Analysis of the effect of coronavirus infection on the heart]. Wissenschaftliche Ergebnisse und Errungenschaften, 2, 43-44. DOI:10.36074/25.12.2020.v2.11

5. Komisarenko, S.V. (2020). Poliuvannia vchenykh na koronavirus SARS-COV-2, shcho vyklykaie COVID-19: naukovi stratehii podolannia pandemii [Hunting of scientists for coronavirus SARS-COV-2, which causes COVID-19: scientific strategies for overcoming the pandemic]. Visn. NAN Ukrainy - NAS Ukraine Bulletin, 8, 29-71 [in Ukrainian].

6. Oryshchyn, N., \& Ivaniv, Yu. (2020). Sertsevosudynni uskladnennia u patsiientiv iz COVID-19: opys klinichnoho vypadku ta ohliad literatury [Cardiovascular complications in patients with COVID-19: description of the clinical case and review of the literature]. Pratsi NTSH Medychni nauky-Proceedings of the NTSh Medical Sciences, 2 (62), 87-98. DOI: $10.25040 /$ ntsh2020.02.08

\title{
СОВРЕМЕННЫЕ ПРЕДСТАВЛЕНИЯ О МОРФОЛОГИЧЕСКОЙ ДИАГНОСТИКЕ РАСПРОСТРАНЕННЫХ СЕРДЕЧНО-СОСУДИСТЫХ ОСЛОЖНЕНИЙ COVID-19 ПО ДАННЫМ ЛИТЕРАТУРЫ И СОБСТВЕННЫХ ГИСТОЛОГИЧЕСКИХ ИССЛЕДОВАНИЙ
}

\section{๑Д. Б. Коваль, Д. О. Кошовская, Т. К. Головатая, А. З. Миколенко, Ю. Н. Орел}

Тернопольский национальный медицинский университет имени И. Я. Горбачевского Моз Украины

PEзЮME. Проблема изучения патогенетического воздействия SARS-COV-2 на дыхательную и сердечно-сосудистую системы в организме человека актуальна, поскольку поражения сердца и коронарных сосудов являются причиной многочисленных летальных случаев и развития осложнений, которые значительно ухудшают качество жизни

Цель - исследовать патогенетические и морфологические особенности основных сердечно-сосудистых осложнений при COVID-19.

Материал и методы. Проведен анализ научной литературы и гистологическое исследование сердца 4-х пациентов, умерших от сердечно-сосудистой недостаточности в больницах Тернопольской области с лабораторно подтвержденной коронавирусной инфекцией.

Результаты. Доказано, что сердечно-сосудистые осложнения COVID-19 связаны с повреждением эндотелия, гиперкоагуляцией (тромбоэмболия легочной артерии, инфаркт миокарда, инсульт) и системным воспалением (миокардит).

Выводы. Причинами развития острой сердечно-сосудистой недостаточности при коронавирусной инфекции являются альтеративно-воспалительные изменения паренхиматозного компонента миокарда, гиперкоагуляция и повреждения эндотелия сосудов.

КЛЮчЕВЫЕ СЛОВА: COVID-19; ендотелиит; инфаркт миокарда; миокардит.

\section{RECENT VIEWS ON MORPHOLOGICAL DIAGNOSTICS OF THE MOST COMMON CARDIOVASCULAR COMPLICATIONS OF COVID-19 ACCORDING TO THE LITERATURE REVIEWS AND OWN HISTOLOGICAL EXAMINATIONS}

\author{
@D. B. Koval, D. O. Koshovska, T. K. Holovata, A. Z. Mykolenko, Yu. M. Orel \\ I. Horbachevsky Ternopil National Medical University
}

SUMMARY. The study of pathogenic impact of SARS-COV-2 on the respiratory and cardiovascular systems of the human body is consequential, as diseases of the heart and coronary blood vessels are the cause of numerous lethal cases and development of complications that noticeably aggravate the quality of patient's life.

The aim - to investigate of pathogenic and morphological peculiarities of the main cardiovascular complications of COVID-19.

Material and Methods. Conducted the analysis of scientific literature and investigated hearts of 4 patients who died from the cardiovascular insufficiency in the hospitals of Ternopil region with laboratory verified coronavirus infection.

Results. Demonstrated that cardiovascular complications of COVID-19 are related with the endothelium damage, hypercoagulation (pulmonary artery embolism, myocardial infarction, stroke) and systemic inflammation (myocarditis).

Conclusions. The reasons of the development of acute cardiovascular failure in patients with COVID-19 are alternative inflammatory changes of the myocardial parenchymal component, hypercoagulation and blood vessels endothelium damage.

KEY WORDS: COVID-19; endotheliitis; myocardial infarction; myocarditis. 